UDC 656.222

Yu. CHIBISOV, G. MOZOLEVICH (Dnipropetrovsk National University of Railway Transport named after Academician V. Lazaryan)

\title{
METHODOLOGY OF RAILWAY NETWORKS RESEARCH
}

Виконано аналіз залежностей між швидкістю, густиною потоку та інтенсивністю руху поїздів на залізничній дільниці. Встановлено взаємозв'язок між вихідним і вхідним потоками поїздів та щільністю поїздів на дільниці; взаємозв'язок між вхідним потоком та швидкістю руху. Наведено ряд випадкових факторів, які можуть впливати на розподіл поїздопотоків по залізничній мережі.

Ключові слова: вантажні перевезення; розподіл поїздопотоків, залізнична мережа; пропускна спроможність; інтенсивність руху; щільність поїздопотоку

Выполнен анализ зависимостей между скоростью, плотностью потока и интенсивностью движения поездов на железнодорожном участке. Установлена взаимосвязь между выходящим и входящим потоками поездов и плотностью поездов на участке, взаимосвязь между входящим потоком и скоростью движения. Приведен ряд факторов, которые могут влиять на распределение поездопотоков по железнодорожной сети.

Ключевые слова: грузовые перевозки; распределение поездопотоков; железнодорожная сеть; пропускная способность; интенсивность движения; плотность поездопотока

The analysis of the relationships between speed, trainflow density and intensity of the train at the railway line was made. The interconnection between the incoming and outgoing flows of trains and the density of trains was established. There was also established the interconnection between the incoming flow and the speed; the average travel time of trains on the line and the accuracy of the speed. In the course of freight transportation its technological process is influenced by lots of random factors. Without the assessment of these factors with the help of determined models for planning and management of the transportation process its efficiency may decrease considerably. density

Keywords: freight transportation; trainflow distribution; railway network; traffic capacity, traffic intensity, flow

\section{Introduction}

In times of shortage of rolling stock, and under the conditions of transferring a large number of rolling stock units into a private ownership there is an increasing importance of rational use of wagon and locomotive fleet, and the minimization of the energy resources in the promotion of freight wagons and freight trainflows. Under the current conditions in the transport market, the railways should focus on quality service to every customer. To maintain the competitiveness of railways the managing stuff needs to adopt new technologies for improving the use of means of transport.

\section{Analysis of researches and publications}

Tasks of the trainflow distribution via a railway network with the use of different criteria were considered by many authors and have lots of algorithms and solutions $[1-3]$. Task of the trainflow distribution between stations is also well represented in the literature [4-7]. The so-called flow tasks are usually divided into smaller ones which are directed to finding a flow distribution in the network in which the extremum of a particular criterion is provided. It is necessary to take into account the limitations imposed by the terms of flows pre- serve the nodes and flows of non-exceedance of the capacity curves. For the solution of typical flow tasks there are developed many efficient algorithms, for example computer-aid calculations called stream programming [8].

Choosing the criteria of decision making for the above mentioned tasks is a very complicated thing. The solution of this task can provide a great advantage in front of the other means of transport. It will also help railway transport to become more competitive and attractive. Optimal route selection is a complicated and multi-criterion task that has not been solved yet.

The analysis of the recent researches and studies showed that the task of the defining the optimal routes of the train running has not a complete decision yet. When researching the railway line [9] a lot of factors are being ignored, such as the interconnection between the arrival and departing intensity under the conditions of the instant increase of the railway line saturation.

The task of choosing the rational traffic distribution via the railway network is the optimization one. A lot of scientific researches were devoted to its solution [10-13]. The scientists solved this problem in the conditions of motion in the network of separate units of the traffic volume (trains, wag- 
ons). Other scientists propose the solution of this problem under the conditions of ownership of separate network sections.

\section{Formulating objectives of research}

Formation of profitable mechanism in the field of freight transportation under the conditions of transport market functioning involves minimizing of their costs. It requires the development of both new technologies and new approaches to the organization of the train traffic volume, operational management improvement.

In addition, various random factors constantly affect a strictly regulated transportation process. Aiming at successful freight transportation it is necessary to assess the factors influencing the transportation time, quality and the amount of the freight transported. Without the assessment of these factors with the help of determined models for planning and management of the transportation process its efficiency may decrease considerably. The affect of various random factors onto the transportation process is estimated in the scientific research [14]. Random factors may emerge because of subjective as well as objective reasons. Objective reasons may be divided into three groups: technical, organizational and economical. The main technical reasons are: the condition of industrial basis of the transportation process (transport means, containers, lifting means, etc.) and the technological level of operations. Organizational reasons are: specialization, scientifictechnical information, means enhancing the quality of transportation, operation of customs and their subdivisions, moral responsibility for the quality of work, etc. Economical reasons are: tariffs, forms and levels of pay, work consumption, material incentives, etc. The main subjective reasons include a professional, general and cultural level of employees, the emotional and psychological features of their characters, the adequacy of personal and public interests, their personal interest in the results of their work [14].

Some of the following criteria may be chosen for defining the optimal route of the trains: route length, time of the train running, mechanical work losses, the costs of the train running, signal facilities, traffic capacity, railway line load and others.

General distribution of train traffic via a railway network can be implemented according to the criterion of total profits of railways. It can be directed to the railway profitability increase. But under the conditions of constant change of train situation on railway sections the obtained distribution may be ineffective. That is why train dispatchers have to correct it under the conditions of operational change of train situation and to determine the rational routes for train handling according to additional selection criteria.

An average cost of 1 ton of cargo in a freight train is proposed to use as a criterion of optimality when choosing the appropriate train traffic distribution. This criterion can provide a transfer of the more valuable cargo for fastest route, which would increase cargo turnover at the railway districts, and speed up the movement of cargo working capital.

Each cargo owner seeks to accelerate the turnover of its own money by reducing the time for procurement, manufacturing and sales of cargo transportation, as cargo delivery speed is quite important in the duration of its life cycle.

Client costs attributable to the move of the goods can be determined with the use of the following formula:

$$
C_{\mathrm{B}}=A q c_{\mathrm{T}} d_{\text {ст }} t_{\text {дост }},
$$

where $A$ - is a daily train traffic in one direction of the given cargo type, wagons;

$q$ - is the average loading of a car on the direction, tn;

$c_{\mathrm{T}}-$ is an average weighted cost for the one ton of cargo, grn;

$d_{\text {ст }}-$ is a discount rate;

$t_{\text {дост }}-$ is the average time of cargo when moving from the dispatch station to the destination one.

The weighted average cost of one ton of cargo is determined with the use of the following formula:

$$
C_{\mathrm{B}}=\sum_{j=1}^{k} \alpha_{j} c_{\text {вантj }},
$$

where $j$ - is a cargo type;

$\alpha_{j}$-is a cargo share of the $j$ type from the total cargo volume in the train;

$c_{\text {вантј }}$ - is an average cost of the $j$ cargo.

Studies conducted in $[9,11,13]$ suggest the following: when solving practical problems of train traffic regulation and management, technical standardization, planning train operation and analysis of patterns trains distribution it is advisable to use the following equation:

$$
n=\lambda \cdot V
$$

where $n$ - traffic intensity, trains per hour;

$\lambda$ - flow density, train per $\mathrm{km}$;

$V$ - train speed, km per hour. 
If one knows two of these three variables, the third is uniquely determined. Among the mentioned variables, there is no one that would depend only on one parameter. But since the traffic intensity is a quantitative characteristic of a transportation process and speed reflects the level of technical equipment and stations, they should be considered as independent variables, and density should be considered as a dependent one. In addition to the mentioned mean values the determination of the following quantities has the great practical and theoretical importance:

- maximum traffic;

- train speed in free conditions (according to calculations or pulling motion graphics);

- the rate at which traffic reaches its maximum $\left(n=n_{\max }\right)$;

- maximum density at which the train movement is impossible $(V \rightarrow 0)$;

- the density at which traffic utmost $\left(n=n_{\max }\right)$.

To characterize the usage of the traffic capacity of a railway section it is reasonable to use the load level, which represents the ratio of the reached traffic intensity $n$ to the maximum traffic intensity $n_{\max }$ of the current section:

$$
\gamma=\frac{n}{n_{\max }} .
$$

This concept allows us to obtain comparable flow characteristics of trains at different sections, as $\gamma$ is a dimensionless quantity and can take any value from 0 to 1 .

Qualitative flow condition can be characterized with the use of the concepts of speed and coefficient of traffic saturation [9].

Ratio of speed of movement $U$ is the ratio of the maximum permissible speed $V_{\text {д }}$ achieved at densities up to free movement speed $V_{\mathrm{B}}$ [9]:

$$
U=\frac{V_{\text {д }}}{V_{\text {в }}} .
$$

This ratio can assess the impact of different density flow speed. The value $U$ is dimensionless and can take any value from 0 to 1 .

Density level of a section is the ratio of the flow density $\lambda$ in different sizes to a maximum traffic density $\lambda_{\max }[9]$ :

$$
\rho=\frac{\lambda}{\lambda_{\max }} .
$$

The most important characteristic of a railway section is the maximum intensity of the flow of trains (capacity) [9]. The use of a traffic capacity and optimization of its development depends largely on meeting the needs of the population in the transportation of goods and passengers.

An analysis of the literature $[4,9,13]$ revealed that in present the calculation of a traffic capacity of a railway section means to determine the socalled restrictive section. It is necessary to determine the amount of trains that may be transferred through this section, depending on the technical equipment of the section, and means of organization of trains.

A traffic capacity of a railway section is essentially a measure of the flow of train service, the value of which affect the plan and profile of a track, technical equipment of the sections, pullperformance of the locomotives, the type of timetable, weight and length of trains of different categories, the maximum allowable speed, climate weather conditions and so on. Very important in this respect is also the choice of control modes by the train machinists.

Assuming that the flow consists of freight trains with similar specifications, and locomotive drivers have the same skills, then if an interval between trains equals $6 \mathrm{~min}$, then under the ideal conditions a traffic capacity should reach 240 trains per day. Value of conditions, enabling the movement of such intensity, is extremely rare, and in the event of such a situation the flow of trains becomes extremely fragile. That is why it is almost impossible to reach the specified maximum traffic capacity. Therefore, considering the movement of trains and assessing the possible flow rate, one needs to characterize substantially not only one railway section, but also under appropriate conditions the whole complex (train flow - railway section - locomotive drivers). This is because locomotive drivers can also make a great impact on a traffic capacity. So, if there is a possibility to replace human completely with the automatic train control system, a traffic capacity can be significantly increased. In addition, the characteristics of a train flows (speed, density, homogeneity, etc.) also makes a great influence on a train motion, as well as on a traffic capacity.

A change in the reaction of a railway section depending on the different traffic volumes shows the necessity to determine a traffic capacity not in a separate cut, but on the entire length of the section. This reaction can show the correlation of intensities of the input flow and the output one from the train transit flow. 
When reaching a saturation state any further increase in the intensity of the input flow of trains reduces the size of the output flow. The latter occurs in cases where the growth in the number of trains on a section quickly increases the density of their distribution, following the green traffic lights increasingly changes to yellow and red.

\section{Conclusions}

There was researched the influence of the railway line load onto the main indexes of the train running. There was figured out that increasing the quantity of the trains in the arrival intensity causes the dramatic decrease of the speed of the running trains. That means it is important to define the rational quantity of the trains on each railway line; every extra train on the line causes an increase of the time and work losses. So, it is necessary to consider different variants of directing the trains in the railway junction when reaching the saturation point of the traffic capacity.

The results obtained in this research may be useful when choosing the route of directing the trainflow in the railway junction, railway direction or railway network on the whole at the time of the summer schedule, increasing the arrival intensity of the trains or at the time when one track of the railway direction is closed.

It was also determined the connection between an increase of the cargo delivery speed and decrease of the costs concerning the rational distribution of train traffic volume between the routes according to the criterion of the average weighted cost for 1 ton of cargo in the train. First of all, the technology will help the dispatch service of railways and the directions to carry out operational distribution of train traffic volume between the separate stations on a railway network.

\section{BIBLIOGRAPHY}

1. Форд, Л. Р. Потоки в сетях [Текст] / Л. Р. Форд., Д. Р. Фалкерсон [пер. с англ.] - М.: «Мир», 1966. - $372 \mathrm{c}$.

2. Березина, Л. Ю. Графы и их применение: Пособие для учителей [Текст] / Л. Ю. Березина/ - М.: Просвещение, 1979. - 143 с.
3. Носов, В. А. Комбинаторика и теория графов / В. А. Носов. - М.: Издат-во: Московский государственный институт электроники и математики, 1999.

4. Юнушкин, А. А. Распределение потоков в транспортных сетях (зарубежный опыт) [Текст] / А. А. Юнушкин // Вестник транспорта. - 2007. № 12. - C. 31-34.

5. Поттгофф, Г. Теория транспортных потоков [Текст] / Г. Поттгофф. - Берлин. - 618 с.

6. Андерсон, Д. А. Дискретная математика и комбинаторика [Текст] / Джеймс А. Андерсон [пер. с англ.] - М.: Вид. дім «Вільямс», 2004. - 960 с.

7. Босов, А. А. Визначення раціональних маршрутів руху поїздів на мережі доріг [Текст] / А. А. Босов, Ю. В. Чибісов // Вісник Дніпропетр. нац. ун-ту залізн. трансп. ім. акад. В. Лазаряна. Вип. 34 - Д., 2010.- С. 180-188

8. Йенсен, П. Потоковое программирование [Текст] / П. Йенсен, Д. Барнес // - М.: Радио и связь, 1984. - $392 \mathrm{c}$.

9. Левин, Д. Ю. Оптимизация потоков поездов [Текст] / Д. Ю. Левин - М.: Транспорт, 1988. - 175 с.

10. Босов, А. А. Визначення раціональних маршрутів руху поїздів на мережі доріг [Текст] / А. А. Босов, Ю. В. Чибісов // Вісн. Дніпропетр. нац. ун-ту залізн. трансп. ім. акад. В. Лазаряна. - Д., 2010. Вип. 34. - С. 180-188

11. Чибісов, Ю. В. Вибір раціональних варіантів пропуску поїздопотоку по паралельних залізничних лініях за економічним критерієм [Текст] / Ю. В. Чибісов // Вісник НТУ «ХПИ»- Х., 2012. - Вип. 68. C. $151-155$.

12. Чибісов, Ю. В. Математична модель вибору раціональних варіантів пропуску поїздопотоків по залізничній мережі [Текст] / Ю. В. Чибісов, Г. Я. Мозолевич // Восточно-европ. журнал передовых технологий. - 2012. - № 3/11 (57). - С. 37-41.

13. Nesterenko, G. I. Optimal route selection when distributing the freight trainflow in the railway junction with the consideration of the level of the traffic capacity saturation / G. I. Nesterenko, Yu. V. Chibisov // Вісник Східноукраїнського нац. ун-ту ім/ Володимира Даля. - 2012. - № 3 [174] - С. 138-143.

14. Adolfas Baublys ASSESSMENT OF STATISTICAL PROBABILITY OF THE TECHNOLOGICAL TRANSPORTATION PROCESS // TRANSPORT - 2002, Vol. XVII, No 4, 127-136

Prof. E.S. Aloshynskym D. Sc. (Tech.) recommended this articlt to be publication

Received Dec. 10, 2013.

Accepted Dec. 11, 2013. 